\title{
Control of Meloidogyne paranaensis mediated by silicon
}

\author{
Anderson Cascione Gripp Bicalho ${ }^{1 \oplus}$, Santino Aleandro da Silva ${ }^{2}$, Andressa Cristina Zamboni Machado ${ }^{2 *}(\mathbb{C}$
}

\author{
Universidade Estadual de Londrina - Depto. de Agronomia, \\ Rod. Celso Garcia Cid, Pr 445, km 380 - 86057-970 - \\ Londrina, PR - Brasil. \\ 2Instituto Agronômico do Paraná - Depto. de Proteção de \\ Plantas, Rod. Celso Garcia Cid, km 375 - 86047-902 - \\ Londrina, PR - Brasil. \\ Corresponding author <andressaczmachado@hotmail.com>
}

Edited by: Roy Neilson

Received February 13, 2019

Accepted November 28, 2019
ABSTRACT: The potential of silicon (Si) to control nematodes is often reported in association with the resistance induction mechanism. The objective of this work was to evaluate the hypothesis of resistance induction in plants against nematodes through the application of $\mathrm{Si}$. In vitro experiments were carried out to evaluate the effect of $\mathrm{Si}$ and potassium chloride $(\mathrm{KCl})$ on the hatching and mortality of Meloidogyne paranaensis juveniles. For the purpose of a greenhouse experiment, tomato plants were used as a model for bifurcated roots, using the respective control treatments, $\mathrm{KCl}$ and distilled water. Ten days after treatment, 2,000 eggs of M. paranaensis were inoculated. At 55 days post-inoculation, the reproduction factor and number of nematodes per gram of root were evaluated. Additionally, the tissue nutrient concentration and gas exchange variables were analyzed. Silicon reduces nematode viability, when in direct contact with the nematode in in vitro experiments and in bifurcated plants. When plants were treated with $\mathrm{Si}$ on one side of the root, no nematode control was observed on the opposite corresponding side. Results suggested that Si has a positive effect on the reduction of $M$. paranaensis population, but probably induced resistance to nematode only through direct action. Keywords: Solanum lycopersicum, management, root-knot nematode

\section{Introduction}

Root-knot nematodes are the main phytoparasitic group of nematodes worldwide, causing extensive losses in important agricultural crops (Moens et al., 2010). There are more than 100 Meloidogyne species currently described but certain species such as $M$. enterolobii, M. exigua, M. fallax, M. minor, and M. paranaensis, previously and even now still neglected, are emerging as a concern for agriculture (Elling, 2013).

Meloidogyne paranaensis is the most damaging species to Brazilian coffee growing areas. Losses may reach $50 \%$ of the coffee yield (Carneiro et al., 1996). Meloidogyne paranaensis is widespread in coffee plantations mainly in the state of Paraná, which accounted for approximately $52 \%$ of all root-knot nematode infestations, varying according to the region sampled (Carneiro et al., 1996). Although coffee is the primary host of this species, $M$. paranaensis has also been detected in tobacco, tomato and watermelon (Carneiro et al., 1996).

In this context, the search for alternatives to control this parasite is essential to the improvement of field management strategies. Consequently, the management of the nutritional condition of plants has become a subject for debate in terms of capacity to induce resistance to nematodes. Among the more promising elements is silicon $(\mathrm{Si})$, but there are few reports in the literature about the capacity of Si to control nematodes. Previous studies have reported the use of calcium silicate altering $M$. javanica reproduction rates (Dutra, 2018). In coffee plants, Si application is responsible for increases in plant resistance to $M$. exigua, decreasing the reproductive rates (Silva et al., 2010). Roldi et al. (2017) observed significant reductions in the reproduction of M. paranaensis in coffee plants after treatment with Si.
Moreover, $\mathrm{Si}$ is reported to have nematicide activity (Jain and Singh, 2006).

Therefore, it is suggested that the application of $\mathrm{Si}$ could be a promising tool for the management of nematodes. Nevertheless, the mechanisms involved in the control of nematodes mediated by Si needed to be researched. It is proposed that resistance induction is involved in the plant active defense response after the application of Si (Ye et al., 2013), but this hypothesis was not tested for nematode control. Therefore, the objective of the present work was to evaluate the effect of $\mathrm{Si}$ on $M$. paranaensis parasitism in tomato plants, herein used as a suitable host model plant to study nematode pathogenicity and plant defense responses involved in this pathosystem.

\section{Materials and Methods}

Two in vitro experiments were carried out at Londrina, in the state of Paraná, Brazil $\left(23^{\circ} 21^{\prime} 20.0^{\prime \prime}\right.$ S, $51^{\circ} 09^{\prime} 58.2^{\prime \prime} \mathrm{W}$, altitude of $610 \mathrm{~m}$ ) to evaluate the effect of the suspension of potassium silicate and potassium chloride $(\mathrm{KCl})$ under $M$. paranaensis control. Potassium silicate was used as the silicon source and was composed of $12 \%$ soluble potassium oxide $\left(\mathrm{K}_{2} \mathrm{O}\right)$ and $12 \%$ water soluble silicon, with a density of 1.38 $\mathrm{g} \mathrm{L}^{-1}$. Potassium chloride $(\mathrm{KCl})$ was included to isolate the effect of potassium present in the potassium silicate used. Dosages used were $0.008 \mathrm{~g} \mathrm{~mL}^{-1}(\mathrm{KCl})$ and $0.041 \mathrm{~g}$ $\mathrm{mL}^{-1}(\mathrm{Si}) ;$ a third treatment with only distilled water was used as control.

The inocula used were composed of a mix of M. paranaensis populations, originally obtained from coffee roots in the state of Paraná. Populations were identified with both $\alpha$-esterase phenotypes (Carneiro et al., 2000) and morphological approaches (Hartman 
and Sasser, 1985). These populations are routinely multiplied on coffee (Coffea arabica L.) cv. Mundo Novo and tomato (Solanum lycopersicum L.) cv. Santa Clara under greenhouse conditions. Egg masses were extracted from tomato roots and incubated under a Baermann funnel to acquire second-stage juveniles (J2) of M. paranaensis (Machado et al., 2010). Hatched juveniles were collected after $24 \mathrm{~h}$ and the suspension was calibrated to 50 juveniles $\mathrm{mL}^{-1}$ with the use of a Peters slide, under a light microscope. Additionally, eggs were collected from tomato roots, which were picked (2 $\mathrm{cm})$, inserted in a lidded pot, and shaken for $1 \mathrm{~min}$ in a hypochlorite solution $(0.5 \%)$ to solve the gelatinous matrix and expose the eggs (Hussey and Barker, 1973). Subsequently, the suspension obtained was washed and calibrated to 50 eggs $\mathrm{mL}^{-1}$ with the use of a Peters slide, under a light microscope.

The experimental unit was composed of glass tubes $12 \mathrm{~mm}$ in diameter and $75 \mathrm{~mm}$ high, with a volume of $6 \mathrm{~mL}$. Five $\mathrm{mL}$ of an aqueous suspension with products and $1 \mathrm{~mL}$ of a suspension containing nematodes were added to each tube, using a semiautomatic pipette. The control was composed of tubes containing $5 \mathrm{~mL}$ of distilled water and $1 \mathrm{~mL}$ of a suspension containing nematodes. Tubes were incubated in a BOD (Biochemical Oxygen Demand) incubator, at $25{ }^{\circ} \mathrm{C}$, for seven days. Experiments with juveniles were evaluated $24 \mathrm{~h}$ after the installation, by counting the percentage of mobile and immobile juveniles. Hatching was evaluated seven days after the installation of experiments, by counting the number of hatched juveniles in the suspension.

Additionally, one experiment was conducted under greenhouse conditions at the Instituto Agronômico do Paraná, from 16 Apr to 09 July 2016, with temperatures ranging from 16 to $43{ }^{\circ} \mathrm{C}$. Soil used in the experiment was sterilized $\left(160{ }^{\circ} \mathrm{C} / 5 \mathrm{~h}\right)$ and was composed of $34 \%$ clay, $8 \%$ silt and $58 \%$ sand, with $51.5 \mathrm{mg} \mathrm{kg}^{-1}$ of soluble silicon. Tomato seedlings from the Santa Clara cv. were transplanted 15 days after sowing to $500 \mathrm{~mL}$-capacity plastic pots, containing $400 \mathrm{~mL}$ of sterilized soil. Immediately before the transplanting, the roots and the stem base of seedlings were cut to separate each half part of the roots in an individual plastic pot, according to the bifurcated roots methodology described by Fabry et al. (2007).

After the transplanting, seedlings were treated with $\mathrm{Si}_{1} \mathrm{KCl}$ and distilled water with the following treatments: $\mathrm{T} 1=$ non-bifurcated root, treated with water, without nematode; T2 (bifurcated root), in which $\mathrm{T} 2 \mathrm{~A}=$ one side of the root treated with silicon, with nematode and $\mathrm{T} 2 \mathrm{~B}=$ another side of the root treated with water, without nematode; T3 (bifurcated root), in which $\mathrm{T} 3 \mathrm{~A}=$ one side of the root treated with silicon, without nematode and $\mathrm{T} 3 \mathrm{~B}=$ another side of the root treated with water, with nematode; T4 (bifurcated root), in which $\mathrm{T} 4 \mathrm{~A}=$ one side of the root treated with potassium chloride, with nematode and $\mathrm{T} 4 \mathrm{~B}=$ another side of the root treated with water, without nematode;
$\mathrm{T} 5$ (bifurcated root), in which $\mathrm{T} 5 \mathrm{~A}=$ one side of the root treated with potassium chloride, without nematode and $\mathrm{T} 5 \mathrm{~B}=$ another side of the root treated with water, with nematode; and $\mathrm{T} 6$ (bifurcated root), in which $\mathrm{T} 6 \mathrm{~A}=$ one side of the root treated with water, with nematode and $\mathrm{T} 6 \mathrm{~B}=$ another side of the root treated with water, (without nematode).

A silicon solution was prepared with $4.82 \mathrm{~mL}$ of Fertisilício ${ }^{\circledR}$ diluted in $160 \mathrm{~mL}$ of water. A second treatment, containing only potassium chloride $(\mathrm{KCl})$ at the concentration of $60 \%$ of $\mathrm{K}_{2} \mathrm{O}$, was included to isolate the effect of potassium present in Fertisilício ${ }^{*}$. The solution was prepared with $1.33 \mathrm{~g}$ of $\mathrm{KCl}$ diluted in $160 \mathrm{~mL}$ of water. Additionally, a third treatment with only distilled water was used as control. Seedlings were irrigated daily, over a period of 10 days, with 3 $\mathrm{mL}$ of solution containing water, Fertisilício ${ }^{\circledR}$ or $\mathrm{KCl}^{-}$ in concentrations of $0.041 \mathrm{~g} / \mathrm{mL}$ (Si) and $0.0083 \mathrm{~g} \mathrm{~mL}^{-1}$ (KCl).

After treatments with $\mathrm{Si}$ or $\mathrm{KCl}$, tomato seedlings were inoculated with a suspension containing 2,000 eggs of $M$. paranaensis into the soil in two holes beside the root system of each half part of the tomato seedlings. Tomato plants were fertilized once with $3 \mathrm{~g}$ per plant of Osmocote Plus $\left(15 \% \mathrm{~N}, 9 \% \mathrm{P}_{2} \mathrm{O}_{5}, 12 \% \mathrm{~K}_{2} \mathrm{O}, 1 \% \mathrm{Mg}\right.$, $2.3 \% \mathrm{~S}, 0.05 \% \mathrm{Cu}, 0.45 \% \mathrm{Fe}, 0.06 \% \mathrm{Mn}, 0.02 \% \mathrm{Mo}$ ). Plants were irrigated daily, according to the climatic conditions and crop phenology.

Analyses of root tissues for quantification of both macro- and micronutrients were carried out: i) before the

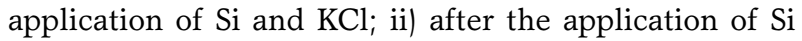
and $\mathrm{KCl}$ but immediately before the inoculation; and iii) 55 days after inoculation (DAI). Samples were composed of five roots of each treatment at each evaluation date. Roots were washed in tap water and sent to the laboratory responsible for soil analyses. Macronutrients $(\mathrm{N}, \mathrm{P}, \mathrm{K}, \mathrm{Ca}, \mathrm{Mg}, \mathrm{S}, \mathrm{Na})$ and micronutrients $(\mathrm{B}, \mathrm{Cu}, \mathrm{Fe}$, $\mathrm{Mn}, \mathrm{Mb}, \mathrm{Zn}, \mathrm{Al}, \mathrm{Ni}, \mathrm{Si}$ ) were quantified in the samples.

Physiological analyses of plants were also carried out at 55 DAI. Measurements were taken using an infrared gas analyzer, from $08 \mathrm{~h} 30$ to $11 \mathrm{~h} 30$. Data were collected in leaves from the upper third of plants, one leaf per plant, 5 plants per treatment. Data collected were: photosynthetic rate $\left(\mathrm{A}, \mu \mathrm{mol} \mathrm{CO} \mathrm{m}^{-2} \mathrm{~s}^{-1}\right)$, stomatal conductance, (gs, $\left.\mathrm{mmol} \mathrm{H} \mathrm{H}_{2} \mathrm{~m}^{-2} \mathrm{~s}^{-1}\right)$, transpiration $(\mathrm{E}$, $\left.\mathrm{mmol} \mathrm{H}_{2} \mathrm{O} \mathrm{m}^{-2} \mathrm{~s}^{-1}\right), \mathrm{CO}_{2}$ internal concentration $(\mathrm{Ci}, \mathrm{mmol}$ $\left.\mathrm{H}_{2} 0 \mathrm{~m}^{-2} \mathrm{~s}^{-1}\right)$, and leaf temperature $\left(\mathrm{Tf},{ }^{\circ} \mathrm{C}\right)$. The instant efficiency in water use (EiUA, A/gs), extrinsic efficiency in water use (EeUA, A/E) and instant efficiency of carboxylation (EiC, A/Ci) were calculated from data obtained.

The reproduction of $M$. paranaensis was evaluated 55 DAI. Pots were immersed in a bucket containing $4 \mathrm{~L}$ of water to separate roots from soil. Roots were washed with tap water, dried on absorbent paper and the fresh weight determined. The half parts of each root system were then separately processed for nematode extraction by blender in a solution of $1 \% \mathrm{NaOCl}$ (Boneti and Ferraz, 
1981). The final nematode population was determined by counting the number of eggs and juveniles with the assistance of a Peters slide. Finally, the reproductive factor $(\mathrm{RF}=$ Final Population/ Initial Population) (Oostenbrink, 1966) and the number of nematodes per gram of roots (Nema/g) was calculated.

In vitro experiments were arranged in a completely randomized design, with three treatments (distilled water, $\mathrm{Si}$ and $\mathrm{KCl}$ ) and ten replicates per treatment; a greenhouse experiment was also arranged in a completely randomized design, with six treatments and ten replicates per treatment. Data from the in vitro experiment were analyzed using the Agricolae package in R 2.15.2 (R Core Team, 2015) and means were compared by ScottKnott test $(p<0.05)$. Data from greenhouse experiment were analyzed by Shapiro Wilk test (normality) and FR and Nema/g were $\ln (x+1)$ transformed prior to one-way analysis of variance (ANOVA). Later, treatments were separated by Fisher's least significance difference (LSD, $p<0.05$ ), using the Agricolae package (Mendiburu, 2015). Next, data obtained in the physiological analyses were studied using multivariate techniques. To acquire the data, hierarchical clustering analysis (Ward's method), based on a principal component analysis (PCA) obtained a priori, was performed using average values for each variable provided by the $\mathrm{R} 2.15 .2$ software program (R Development Core Team, 2015).

\section{Results and Discussion}

It was evident that $\mathrm{Si}$ showed a direct effect on nematodes, since after $24 \mathrm{~h}$ in contact with juveniles, mobility was reduced 98.81\% (Experiment 1) and $98.75 \%$ (Experiment 2), whereas in the treatment with $\mathrm{KCl}$, the viability of juveniles was higher than that observed in the treatment with distilled water. In relation to hatching of juveniles (Table 1), at seven days in contact with the treatments, no significant difference was observed between $\mathrm{Si}$ and $\mathrm{KCl}$ in Experiment 1 . However, when compared with distilled water, both treatments reduced the hatching of juveniles. In Experiment 2, Si reduced the hatching of juveniles, but $\mathrm{KCl}$ did not show this effect, contrary to our observations in Experiment 1.

Table 1 - Percentage of immobile juveniles (\% JIM) after $24 \mathrm{~h}$ in contact with silicon (Si) and $\mathrm{KCl}$ and percentage of juvenile hatching of Meloidogyne paranaensis after seven days in contact with the products. In vitro experiment.

\begin{tabular}{lccrr}
\hline \multirow{2}{*}{ Treatment } & \multicolumn{2}{c}{ Experiment 1 } & \multicolumn{2}{c}{ Experiment 2 } \\
\cline { 2 - 5 } & Hatching $^{1}$ & $\% \mathrm{JIM}^{2}$ & Hatching $^{1}$ & \multicolumn{1}{c}{$\% \mathrm{JM}^{2}$} \\
\hline $\mathrm{Si}$ & $12.40 \mathrm{~b}$ & $98.81 \mathrm{a}$ & $12.00 \mathrm{~b}$ & $98.75 \mathrm{a}$ \\
$\mathrm{KCl}$ & $14.75 \mathrm{~b}$ & $11.01 \mathrm{c}$ & $24.24 \mathrm{a}$ & $8.56 \mathrm{c}$ \\
Distilled water & $21.43 \mathrm{a}$ & $17.50 \mathrm{~b}$ & $31.39 \mathrm{a}$ & $23.09 \mathrm{~b}$ \\
\hline
\end{tabular}

$\mathrm{Si}=$ potassium silicate; $\mathrm{KCl}=$ potassium chloride; ${ }^{1}$ Values are percentages; ${ }^{2}$ Each value represents the mean of 10 replicates. Values followed by the same letter in column did not differ statistically by Least Significant Difference test $(p<0.05)$.
In accordance with the results, we can infer that $\mathrm{Si}$ and $\mathrm{KCl}$ had a direct effect on nematodes, since both were responsible for a more than $50 \%$ reduction in juvenile hatching. Moreover, the observed mortality rate of juveniles higher than $98 \%$ in treatments with $\mathrm{Si}$ corroborates this assertive. Comparing the results of the in vitro test with previous reports about the effect of $\mathrm{Si}$ on nematode control, there is correspondence with Mattei and Dias-Arieira (2015), which observed a reduction in the hatching of $M$. javanica when treated with silicate products such as potassium silicate $\left(10 \% \mathrm{~K}_{2} \mathrm{O}\right.$ and $10 \%$ $\mathrm{Si})$, a compost of $17.43 \%$ silicon dioxide $\left(\mathrm{SiO}_{2}\right), 20.56 \%$ aluminum oxide $\left(\mathrm{Al}_{2} \mathrm{O}_{3}\right), 9.82 \%$ sulphur and $1.31 \%$ calcium oxide $(\mathrm{CaO})$ and $\mathrm{Ca}$ metasilicate $\left(\mathrm{CaSiO}_{3}\right.$, composed of $52 \% \mathrm{SiO}_{2}, 44 \% \mathrm{CaO}, 0.3 \% \mathrm{MgO}$ and $0.2 \%$ $\mathrm{Fe}_{2} \mathrm{O}_{3}$ ). However, for $M$. paranaensis, there has been no information until now about the effect of Si on its control.

In relation to the $\mathrm{Si}$ and $\mathrm{K}$ concentration in plants, the treatment with $\mathrm{Si}$ did not result in an increase in its concentration, in comparison with other treatments (Figure 1). Concentrations of these elements was higher in the non-bifurcated roots treatment (T1). Additionally, roots showed a lower concentration of $\mathrm{Si}$ in the beginning, increasing in concentration in the second evaluation, whereas the concentration of $\mathrm{K}$ was similar throughout the experimental period. Huang et al. (2011) affirmed that non-accumulating plants, such as tomato and coffee, concentrate the major part of $\mathrm{Si}$ in the roots compared with the shoots, which could explain the increase in $\mathrm{Si}$ content in tomato roots throughout the experimental period.
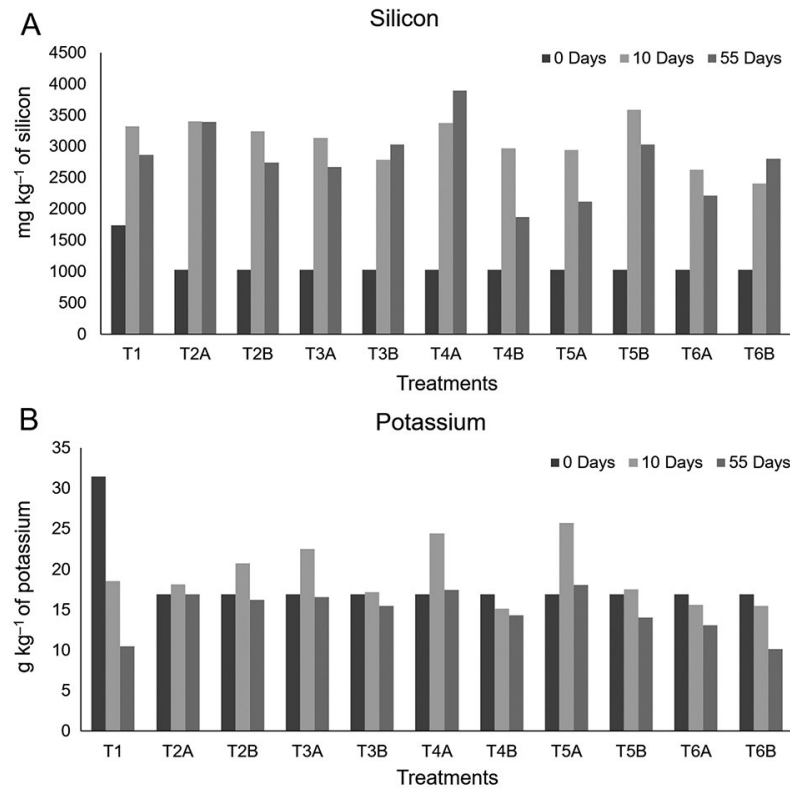

Figure $\mathbf{1}$ - Chemical analysis of radicular tissues (Silicon = Si and potassium $=\mathrm{K}$ ) in three evaluation times: 0 days before treatments; 10 days after treatments and before inoculation; 55 days after the inoculation of Meloidogyne paranaensis. $\mathrm{A}=\mathrm{Si}$ concentration; $\mathrm{B}$ $=\mathrm{K}$ concentration 
In relation to the physiological aspects of plants, in general, the parasitism of $M$. paranaensis did not interfere in the photosynthesis of tomato plants, not in the transpiration, stomatal conductance, internal $\mathrm{CO}_{2}$ concentration, water use efficiency, leaf temperature and internal carboxylation efficiency processes (data not shown). Principal component analysis based on physiological parameters showed that $61 \%$ of the total variation was associated with the first component (Figure 2). The PCA cluster analysis (Ward) allowed for the separation of treatments into two distinct and well-defined groups: i) treatments $\mathrm{T} 1, \mathrm{~T} 3 \mathrm{~A}$, and $\mathrm{T} 3 \mathrm{~B}$; ii) all other treatments. The clustering of treatments with indirect application of $\mathrm{Si}$ with $\mathrm{T} 1$, our standard without nematode, could indicate that, although the presence of $M$. paranaensis on one side of roots, and the application of $\mathrm{Si}$ on another side compensated for the stress caused by the nematode in the plant. A number of reports indicate that Si partially preserves the photosynthetic capacity of plants infected by pathogens (Debona et al., 2017). When Si was applied together with $M$. paranaensis, its absorption by roots could have been impaired so this effect was lower, since T2A and T2B clustered separately from the group of $\mathrm{T} 1$.

As regards plant development, differences were observed in the fresh root weight (FRW) between the treatments, which differentiated poorly between themselves (Table 2). T4A was the treatment with the lowest value for FRW.

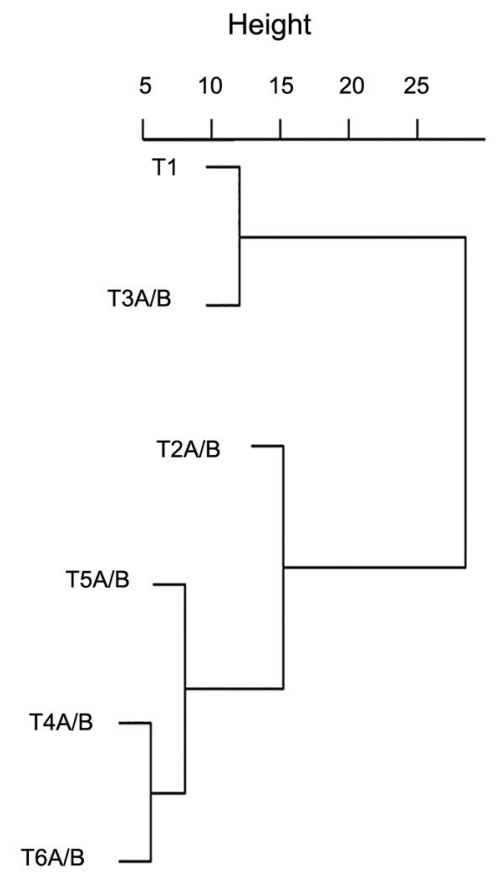

Figure 2 - Dendrogram illustrating the dissimilarity between treatments obtained by the Ward algorithm, based on Euclidean distance, calculated from the average of physiological processes of tomato plants inoculated with Meloidogyne paranaensis and treated or not with silicon and potassium chloride.
Roots treated directly with $\mathrm{Si}(\mathrm{T} 2 \mathrm{~A})$ or $\mathrm{KCl}$ (T4A) allowed for lower nematode multiplication. In both cases, nematode reproduction was reduced by more than $50 \%$, based on reproduction factor $(\mathrm{RF})$. The number of nematodes per gram of roots (Nema/g) exhibited similar results, with the lowest value recorded for T2A $(2,566$ Nema/g). Debona et al. (2017) reported that insoluble silica can be found in the roots, but its content is higher beneath the cuticle and in the plant cell walls. The deposition of $\mathrm{Si}$ in plant cell walls acts as a physical barrier to avoid the penetration of plant pests and pathogens (Debona et al., 2017) and this accumulation could explain the lower number of nematodes in roots treated directly with $\mathrm{Si}$, although we did not evaluate the penetration rate in each case.

In certain reports, the effect of $\mathrm{Si}$ on total cumulative fecundity and the intrinsic rate of increase of aphids, as Myzus persicae in plants of Zinnia elegans treated with Si was observed (Ranger et al., 2009). For nematodes, there are no reports on the effect of $\mathrm{Si}$ on the fecundity of females, but this could be evaluated in future studies in order to better explain the lower multiplication rates observed in plants treated with $\mathrm{Si}$, as in the present work. Moreover, effects on the epidemiological process of plant diseases had been reported as a delay in the incubation period or the latent period, as reported by Cacique et al. (2013) for Pyricularia oryzae causing blast

Table 2 - Fresh root weight (FRW) of tomato plants (cv. Santa Clara), with or without the application of silicon or potassium chloride, reproduction factor (RF) and number of nematodes per gram of roots (Nema/g) of Meloidogyne paranaensis under different treatments, 55 days after inoculation.

\begin{tabular}{lccc}
\hline Treatment $^{1}$ & $\mathrm{FRW}^{2}$ & $\mathrm{RF}^{2}$ & $\mathrm{Nema} / \mathrm{g}^{2}$ \\
\hline T1 & $15.81 \mathrm{a}$ & - & - \\
T2A & $11.45 \mathrm{bcd}$ & $18.17 \mathrm{~b}^{4}$ & $2,566 \mathrm{~b}$ \\
T2B & $12.40 \mathrm{abc}$ & - & - \\
T3A & $9.78 \mathrm{~cd}$ & - & - \\
T3B & $10.83 \mathrm{bcd}$ & $42.31 \mathrm{a}$ & $6,094 \mathrm{a}$ \\
T4A & $8.87 \mathrm{~d}$ & $17.61 \mathrm{~b}$ & $3,085 \mathrm{~b}$ \\
T4B & $9.77 \mathrm{~cd}$ & - & - \\
T5A & $10.48 \mathrm{bcd}$ & - & - \\
T5B & $13.29 \mathrm{ab}$ & $37.13 \mathrm{a}$ & $5,806 \mathrm{a}$ \\
T6A & $11.62 \mathrm{bcd}$ & $36.76 \mathrm{a}$ & $5,626 \mathrm{a}$ \\
T6B & $11.81 \mathrm{bcd}$ & - & - \\
\hline
\end{tabular}

${ }^{1} \mathrm{~T} 1$ = non-bifurcated root, treated with water, without nematode; $\mathrm{T} 2$ (bifurcated root), in which $\mathrm{T} 2 \mathrm{~A}=$ one side of the root treated with silicon, with nematode and $\mathrm{T} 2 \mathrm{~B}=$ another side of the root treated with water, without nematode; T3 (bifurcated root), in which T3A = one side of the root treated with silicon, without nematode and $\mathrm{T} 3 \mathrm{~B}=$ another side of the root treated with water, with nematode; T4 (bifurcated root), in which T4A = one side of the root treated with potassium chloride, with nematode and $\mathrm{T} 4 \mathrm{~B}=$ another side of the root treated with water, without nematode; $T 5$ (bifurcated root), in which $T 5 A=$ one side of the root treated with potassium chloride, without nematode and T5B = another side of the root treated with water, with nematode; and T6 (bifurcated root), in which $T 6 A=$ one side of the root treated with water, with nematode and $T 6 B=$ another side of the root treated with water, without nematode). ${ }^{2}$ Each value represents the mean of 10 replicates. Mean values followed by the same letter in columns did not differ according to Least Significant Difference test $(p<0.05)$. 
rice disease. Studies regarding the development of the biological cycle of nematodes in plants amended with $\mathrm{Si}$ could provide information about this possible effect also on nematodes.

Treatments in which $\mathrm{Si}$ and $\mathrm{KCl}$ were applied indirectly in the roots (T3B and T5B) did not affect nematode reproduction, since RF values were statistically equal to the standard treatment, with only distilled water and inoculated with the nematode (T6A). Indeed, the high values obtained for RF and Nema/g in this standard treated only with water confirmed the viability of inocula and the adequate experimental conditions. Considering the rates of reduction in the nematode population $(42 \%)$ observed when the roots were directly treated with $\mathrm{Si}$ in relation to the standard, we can suggest a direct effect of this element, as was also shown in the in vitro experiments.

Several reports have shown a reduction in the nematode population of the root-knot nematodes in the presence of silicates. Coffee plants inoculated with $M$. paranaensis and M. exigua treated with silicates showed a lower amount of galls, eggs and juveniles (Roldi et al., 2017; Silva et al., 2010). In coffee, Si application is associated with the increase in biochemical responses that intensifies the resistance to $M$. exigua through the reduction in its reproductive capacity (Silva et al., 2010). However, there is no information in the published papers about the mechanism by which Si actuates the nematode control, beit through direct action or induction of resistance mechanisms.

In our study, the reduction in the $M$. paranaensis population observed in the presence of $\mathrm{Si}$ under greenhouse conditions may be explained by the capacity of this element to kill nematodes or by the reduction in the motility of juveniles, which could reduce the number of penetrated juveniles and, consequently, their multiplication (Santos et al., 2013). Silva et al. (2010) affirmed that $\mathrm{Si}$ affects the nematode parasitism and potentializes certain biochemical defense mechanisms. However, the greenhouse experiment reported herein reinforces the possibility of exclusion of the hypothesis of resistance induction due to $\mathrm{Si}$ application. Tests using bifurcated roots are based on the principle that to generate systemic acquired resistance or systemic induced resistance, the mechanism must be systemic. Thus, the reaction unleashed by the interaction of an elicitor on one side of roots must be observed on the opposite side (Fabry et al., 2007). In the greenhouse experiment, the effect observed was the contrary, i.e., the control was obtained exclusively in the treatments with the direct application of $\mathrm{Si}$.

Based on these observations, we can conclude that the application of products with $\mathrm{Si}$ or even with $\mathrm{K}$ is a promising tool for managing $M$. paranaensis in an integrated nematode management system. However, studies on the biochemical mechanisms involved and the detailed effect on nematodes are needed as are studies on the use of Si in coffee growing areas to control
M. paranaensis in order to evaluate better dosages and time of application, as well as better silicate sources to improve nematode control. As nutrients, $\mathrm{Si}$ and $\mathrm{K}$ could become important tools to growers, acting on the nutritional aspect of plants and reduction in nematode populations in the field, which reduces costs and improves yield quality.

\section{Authors' Contributions}

Conceptualization: Machado, A.C.Z.; Bicalho, A.C.G.; Silva, S.A. Data acquisition: Bicalho, A.C.G.; Silva, S.A. Data analysis: Machado, A.C.Z.; Bicalho, A.C.G.; Silva, S.A. Design of methodology: Machado, A.C.Z.; Bicalho, A.C.G.; Silva, S.A. Software development: Silva, S.A. Writing and editing: Machado, A.C.Z.; Bicalho, A.C.G.; Silva, S.A.

\section{References}

Boneti, J.I.S.; Ferraz, S. 1981. Modification of the Hussey \& Barker method for extracting Meloidogyne exigua eggs from coffee roots = Modificação do método de Hussey and Barker para extração de ovos de Meloidogyne exigua de raízes de cafeeiro. Fitopatologia Brasileira 6: 533 (in Portuguese).

Cacique, I.S.; Domiciano, G.P.; Moreira, W.R.; Rodrigues, F.A.; Cruz, M.F.A. 2013. Effect of root and leaf applications on soluble silicone on blast development in rice. Bragantia 72: 304-309.

Carneiro, R.M.D.G.; Carneiro, R.G.; Abrantes, I.M.O.; Santos, M.S.N.A.; Almeida, M.R.A. 1996. Meloidogyne paranaensis n. sp. (Nemata: Meloidogynidae), a root-knot nematode parasitizing coffee in Brazil. Journal of Nematology 28: 177-189.

Carneiro, R.M.D.; Almeida, M.R.A.; Quénéhervé, P. 2000. Enzyme phenotypes of Meloidogyne spp. populations. Nematology 2: 645654.

Debona, D.; Rodrigues, F.A.; Datnoff, L. E. 2017. Silicon's role in abiotic and biotic plant stresses. Annual Review of Phytopathology 55: 4.1-4.23.

Dutra, M.R. 2018. Silicon on the controlo $f$ root knot nematodes (Meloidogyne spp.) in bean (Phaseolus vulgaris L.), tomato (Lycopersicon esculentum Mill) and coffee (Coffea arabica L.). = Controle de nematoides de galhas (Meloidogyne spp.) com silicatos, em feijoeiro (Phaseolus vulgaris L.), tomateiro (Lycopersicon esculentum Mill) e cafeeiro (Coffea arabica). (in Portuguese, with abstract in English). Available at: http:// repositorio.ufla.br/jspui/handle/1/32454 [Accessed Sept 14, 2018]

Elling, A.A. 2013. Major emerging problems with minor Meloidogyne species. Phytopathology 103: 1092-1102.

Fabry, C.F.S.; Freitas, L.G.; Godinho, M.T.; Neves, W.S.; Ferraz, S. 2007. Systemic resistance to Meloidogyne javanica induced by Rhizobium etli G12. Nematologia Brasileira 31: 5-9 (in Portuguese, with abstract in English).

Hartman, R.M.; Sasser, J.N. 1985. Identification of Meloidogyne species on the basis of differential host and perineal pattern morphology. p. 69-77. In: Barker, K.R.; Carter, C.C.; Sasser, J.N., eds. An advanced treatise on Meloidogyne. North Carolina State University, Raleigh, NC, USA. 
Huang, C.H.; Roberts, P.D.; Datnoff, L.E. 2011. Silicon suppresses Fusarium crown and root rot of tomato. Journal of Phytopathology 159: 546-554.

Jain, M.; Singh, R.V. 2006. Synthesis, characterization, and biotoxicity of $\mathrm{N} \mathrm{N}$ donor sulphonamide imine silicon (IV) complexes. Bioinorganic Chemistry and Applications 1: 13743.

Machado, A.C.Z.; Siqueira, K.M.S.; Araújo Filho, J.V. 2010. Methods and Techniques in Plant Nematology. VDM Verlag, Saarbrücken, Germany.

Mattei, D.; Dias-Arieira, C.R. 2015. Different sources of silicon in the embryonic development and in the hatching of Meloidogyne javanica. African Journal Agricultural Research 10: 4814-4819.

Moens, M.; Perry, R.N.; Starr, J.L. 2010. Meloidogyne species: a diverse group of novel and important plant parasites. p. 1-13. In: Moens, M.; Perry, R.N.; Starr, J.L., eds. Root-knot nematodes. CABI International, Wallingford, UK.

Oostenbrink, M. 1966. Major characteristics of the relation between nematodes and plants. Meded. Landbouwhogesch. Wageeningen 66: 1-46.
Ranger, C.M.; Singh, A.P.; Frantz, J.M.; Cañas, L.; Locke, J.C. 2009. Influence of silicon on resistance of Zinnia elegans to Myzus persicae (Hemiptera: Aphididae). Environmental Entomology 38: 129-136.

Roldi, M.; Dias-Arieira, C.R.; Silva, S.A.; Dorigo, O.F.; Machado, A.C.Z. 2017. Control of Meloidogyne paranaensis in coffee plants mediated by silicon. Nematology 19: 245-250.

Santos, M.C.V.; Esteves, I.; Kerry, B.; Abrantes, I. 2013. Biology, growth parameters and enzymatic activity of Pochonia chlamydosporia isolated from potato cyst and root-knot nematodes. Nematology 15: 505-506.

Silva, R.V.; Oliveira, R.D.L.; Nascimento, K.J.T.; Rodrigues, F.A. 2010. Biochemical responses of coffee resistance against Meloidogyne exigua mediated by silicon. Plant Pathology 59: 586-593.

Ye, M.; Songa, Y.; Longa, J.; Wanga, R.; Baerson, S.R.; Panc, Z.; Zhu-Salzmand, K.; Xieb, J.; Caib, K.; Luob, S.; Zenga, R. 2013. Priming of jasmonate-mediated antiherbivore defense responses in rice by silicon. Proceedings of the National Academy of Sciences 110: 3631-3639. 